\title{
Influences on recovery of seabirds on islands where invasive predators have been eradicated, with a focus on Procellariiformes
}

\author{
Stephanie B. Borrelle, Philipp H. Boersch-Supan \\ Chris P. Gaskin and David R. TOWns
}

\begin{abstract}
Protecting seabirds is a global conservation priority given that $29 \%$ of seabird species are threatened with extinction. One of the most acute threats to seabirds is the presence of introduced predators, which depredate seabirds at all life stages, from eggs to adults. Consequently, eradication of invasive predators has been identified as an effective and commonly used approach to seabird conservation. Seabird recovery following the eradication of predators is influenced by complex and interacting environmental and demographic factors, and there are gaps in our understanding of species-specific responses. We reflect on the recovery of seabirds on islands cleared of predators, drawing on the equilibrium theory of island biogeography, and synthesize key influences on recovery reported in the literature. We present a regionally specific case study on the recovery of seabird colonies $(n=98)$ in the Hauraki Gulf, New Zealand, which is a hotspot of seabird diversity (27 species), with a long history of eradications of invasive predators. We found that on islands cleared of predators seabirds recover over time, and such islands have more diverse seabird assemblages than islands that never had predators. Recovery appears to be influenced by a suite of site- and species-specific factors. Managers may assume that given enough time following eradication of predators, seabirds will recolonize an island. Although time is a factor, proximity to source populations and human activities has a significant effect on recolonization by seabirds, as do demographic traits, colonizing ability and habitat suitability. Therefore, integrating expected site and species-specific recovery responses in the planning of eradications should help guide post-eradication management actions.
\end{abstract}

\footnotetext{
STEPHANIE B. Borrelle* (Corresponding author) and DAvid R. Towns $\dagger$ Institute for Applied Ecology New Zealand, School of Science, Auckland University of Technology, Private Bag 92006, Auckland 1142, New Zealand

E-mail stephborrelle@gmail.com

Philipp H. Boersch-Supan $\ddagger$ Department of Integrative Biology, University of South Florida, Tampa, USA

Chris P. Gaskin Northern New Zealand Seabird Trust, Auckland, New Zealand

*Also at: Northern New Zealand Seabird Trust, Leigh, Auckland, New Zealand $\dagger$ Also at: Department of Conservation, Newton, Auckland, New Zealand $\ddagger$ Also at: Department of Geography, University of Florida, Gainesville, USA

Received 19 May 2016. Revision requested 28 June 2016.

Accepted 28 July 2016. First published online 19 December 2016.
}

Keywords Animal behaviour, biogeography, conservation, invasive species, restoration, species recovery, threatened species

The supplementary material for this article can be found at https://doi.org/10.1017/So030605316000880

\section{Introduction}

Ceabirds are often abundant on islands (Mulder et al.,

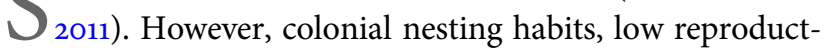
ive output and extended periods of parental care at breeding grounds make seabirds vulnerable to predators (here we use the term predator to describe only non-native mammalian predator species; Furness \& Camphuysen, 1997; Baillie et al., 2004; Wolf et al., 2006; Croxall et al., 2012). Introduced predators are among the most acute and widespread threat to seabirds; for example, rats Rattus spp., which depredate seabirds at every life stage, have invaded at least $80 \%$ of island groups (Towns et al., 2006; Jones et al., 2008; Varnham, 2010; Croxall et al., 2012; Spatz et al., 2014). Consequently, seabirds are one of the most globally threatened groups of animals. Of c. 365 species worldwide, $29 \%$ have been categorized as globally threatened, and $10 \%$ as Near Threatened on the IUCN Red List; 5\% are categorized as Critically Endangered (IUCN, 2015; BirdLife International, 2015). Removal of predators is considered to be one of the most effective strategies for seabird conservation (Jones, 2010; Towns et al., 2013; Jones et al., 2016), and can have positive feedbacks for many biota and ecosystem processes affected by predator presence (Towns et al., 2006; Towns, 2009; Lavers et al., 2010; Jones \& Kress, 2012; Le Corre et al., 2015; Jones et al., 2016).

Despite considerable investment in the removal of introduced predators from islands, the way seabirds respond subsequently remains poorly understood (but see Lavers et al., 2010; Buxton et al., 2014, 2016). Available research has described variable responses among species and islands (Gaze, 2000; Lavers et al., 2010; Ismar et al., 2014). The same traits that make seabirds vulnerable to predation can also inhibit their natural recovery following the removal of predators (Jones et al., 2011; Buxton et al., 2014). Species-specific differences in reproductive output, philopatry and behavioural characteristics influence seabirds' recovery and 
recolonization of newly available habitat (Danchin et al., 1998; Jones et al., 2011; Buxton et al., 2014); for example, there was no observed increase in populations of flesh-footed shearwaters Ardenna carneipes or sooty shearwaters Puffinus griseus following the removal of Norway rats Rattus norvegicus from Titi Island, Marlborough Sounds, in the 1970s (Gaze, 2000). Similarly, on Raoul Island in the Kermadec Islands there was no observed response of white-naped petrels Pterodroma cervicalis following the removal of Norway rats, kiore Rattus exulans, and cats Felis catus during 2002-2004 (Veitch et al., 2011). Conversely, on the same island there was a notable increase in nesting by black-winged petrels Pterodroma nigripennis and wedge-tailed shearwaters Ardenna pacifica, and recolonization by Kermadec petrels Pterodroma neglecta, Kermadec little shearwaters Puffinus assimilis kermadecensis and Kermadec storm petrels Pelagodroma albiclunis (Gaskin, 2012; C. Gaskin, unpubl. data).

Twenty-five species of invasive predators of seabirds have been eradicated successfully from 1,016 islands worldwide (Island Conservation and Invasive Species Specialist Group, 2015; Jones et al., 2016). Responses of seabirds and island ecosystems to these eradications are now being evaluated to identify how seabird colonies recover following predator removals, and whether they can recover to a fully restored state (Jones, 2010). Understanding the recovery of seabirds through space and time following predator eradication is crucial for informing conservation management of seabirds, particularly for species experiencing population declines exacerbated by threats such as fisheries bycatch, marine plastic pollution and climate change (Rolland et al., 2009; Croxall et al., 2012).

The equilibrium theory of island biogeography states that species diversity maintains a dynamic equilibrium over time, influenced by area and ecological diversity (Preston, 1962; MacArthur \& Wilson, 1967; Simberloff, 1974). We would therefore expect seabird diversity on islands to follow this pattern. By comparing islands cleared of introduced predators to islands that have not been affected by the presence of predators or habitat modification we may be able to discern the state of recovery following predator eradication. Here, with a basis of island biogeography theory, we synthesize key influences on seabird recolonization and recovery reported in the literature. We present a case study to test bigeographical influences by examining whether there has been measurable change in seabird assemblages on a sample of islands in New Zealand that have been cleared of invasive predators. We discuss how these biogeographical influences and additional factors of behaviour, demography and within-island habitat availability may be driving seabird recovery. Ideally, pre-eradication population census data would be used for comparative evaluations of species' responses to the removal of threats, but in practice such data are rarely available (Duffy, 1994). We therefore evaluate changes in seabird richness on islands that have been cleared of invasive predators, and compare them to a subset of islands of comparable area that remained free of predators and for which historical seabird species composition data are available. We focus on the Hauraki Gulf, in northern New Zealand, which has 27 species of breeding seabirds (Gaskin \& Rayner, 2013). We used survey data of seabird richness on islands where species were confirmed to be breeding as of the Austral winter of 2015.

\section{Study area}

The islands of the Hauraki Gulf are bounded by the Poor Knights to the north, the Great Barrier Island group to the east and the Aldermen (Ruamaahua) Islands to the south (Fig. 1). The islands included in our study represent a range of ecological states, from extensively modified by invasive mammals, either through previous or current influences (e.g. Rakitu Island), to near pristine (e.g. most islands in the Poor Knights group; Supplementary Material 1; Supplementary Table $\mathrm{S}_{1}$ ). We excluded islands of $<_{1}$ ha because of the small island effect (Burns et al., 2009), and because the survey data on predator presence and seabird populations may be unreliable because of survey constraints (Supplementary Material 2). We also excluded islands that have a permanent residential population because of the potential effects of human activities (e.g. land use, presence of domestic animals, light pollution; Le Corre et al., 2002) on the establishment of seabird colonies. We grouped islands $(n=98)$ into three categories based on predator status: uninvaded $(\mathrm{n}=30)$, invaded $(\mathrm{n}=37)$ and cleared $(\mathrm{n}=31$; Fig. 1; Supplementary Table S4). The climate of the Hauraki Gulf is temperate-humid, with a mean annual temperature of $16^{\circ} \mathrm{C}$, relative humidity of $87 \%$ and mean rainfall of 1,202 $\mathrm{mm}$ (CliFlo, 2016).

\section{Methods}

\section{Data}

Long-term survey data on species confirmed to be breeding on the islands as of the Austral winter of 2015 are from C. Gaskin (unpubl. data) and D.R. Towns (unpubl. data), supplemented by peer-reviewed literature (Fig. 1; Supplementary Table $\mathrm{S}_{4}$ ). The data are presence only. Absence data are rarely available because of the more labour intensive sampling methods and greater economic costs associated with identifying the absence of a species or community (Phillips et al., 2006). In most cases the data are based on observations from up to 30 years ago, with recent presence (i.e. 2004 to present) confirmed through acoustic surveys, occasional island visits and, in some cases, targeted species surveys (e.g. flesh-footed shearwater, Buller's shearwater Ardenna bulleri, grey-faced petrel Pterodroma gouldi, black 


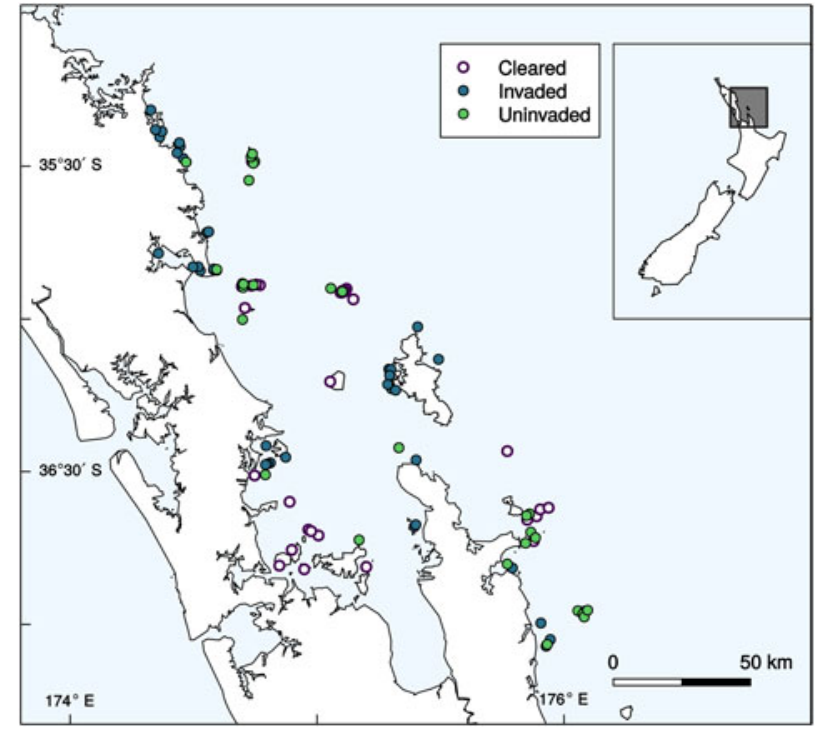

FIG. 1 Locations of seabird colonies $(n=98)$ in the Hauraki Gulf, New Zealand.

petrel Procellaria parkinsoni, Cook's petrel Pterodroma cookii, New Zealand storm petrel Fregetta maoriana; C. Gaskin, unpubl. data) where additional data on other species have been collected. These reports are based on observations; impressions can vary in quality, depending on the methodology, taxon, and skill of the observer (Supplementary Material 2). These biases in sampling effort may influence our results. However, the majority of data were collected by the same group of researchers and any potential biases are likely to be consistent across our study area.

We followed BirdLife International (2015) for taxonomy and nomenclature (Supplementary Material 3). We included 16 seabird species in the study: 14 Procellariiformes, one Sphenisciform and one Pelecaniform (Supplementary Table S2). All exhibit natal site philopatry, and they have a range of population-level responses to introduced predators. Terns (Sternidae), gulls (Laridae) and shags and cormorants (Phalacrocoracidae) were discarded from the analysis because they exhibit ephemeral breeding site selection behaviour (Monaghan, 1996; New Zealand Birds Online, 2015). We have generalized assumptions about behavioural traits, such as sex biases and habitat selection preferences.

We included rats (Rattus rattus, $R$. novegicus, R. exulans), mice Mus musculus, cats, and pigs Sus scrofa (Harris, 1970; Medway, 2001) as known predators of seabirds. Predator eradication data were obtained from the Department of Conservation, D.R. Towns (unpubl. data), Gaskin et al. (2011) and the Database of Island Invasive Species Eradications (Island Conservation and Invasive Species Specialist Group, 2015). Eradications were carried out over 77 years, from 1936 (pigs from Aorangi) to 2011 (R. exulans from Taranga). We used the date of the last successful eradication, where predators had not been identified in biosecurity follow-ups (Supplementary Table $\mathrm{S}_{4}$ ).
Given the paucity of pre-eradication seabird species composition data for cleared islands, temporal analysis of seabird recovery is challenging. We therefore used the available census data for uninvaded islands as a basis for comparisons with seabird species richness of cleared islands (i.e. this is essentially a natural experiment; Oksanen, 2001). This approach simplified potential ecological complications, as we assumed that species richness for a given area would be comparable between islands, given the similar geology and habitat of the islands and the proximity of seabird populations. To assess the stability of seabird assemblages we used historical survey data for six uninvaded 'reference' islands (Table 1), with the earliest data collected in 1928. Although census surveys on the reference islands were not systematic, these data provide information on the observed stability of seabird species composition over the survey period. Species were included on the list only if they were recorded as breeding at that location. Disturbance on these islands varied from historical land clearance by burning, and agricultural use by Māori, to minimal use (Table 1). The reference islands were of pristine or outstanding quality (class I and II; Taylor, 1989; Supplementary Table S1), and therefore we assumed that there was no limitation of available breeding habitat for seabirds.

\section{Analysis}

All statistical analyses were carried out in $R$ v. 3.1 ( $\mathrm{R}$ Development Core Team, 2013). We used generalized linear models with Poisson-distributed errors to estimate the species-area relationship by predator status for all islands (Supplementary Material 4). The models of species richness and island area assume there is a linear increase in the number of species as island area increases but in reality this is limited to the number of seabird species in the region. We assume that the maximum species richness is constrained by the number of species included in the analysis $(n=16)$. Model assumptions of a linear mean variance relationship and of spatially uncorrelated errors were checked using the dispersion test of the $A E R$ package in $R$ (Kleiber \& Zeileis, 2008), and spatial correlation tests of the $s p$, ape and gstat packages (Supplementary Material 4; Paradis et al., 2004; Pebesma, 2004; Bivand et al., 2013).

We considered three models for the species-area relationship by predator status, all being Poisson regressions of a semilog model (i.e. species count, $S$, as response, $\log _{10}(A)$ as predictor). The three models are all Poisson generalized linear models: $S \sim$ Poisson $(\mu)$ with log link, such that $\log \mu(S)=\beta \boldsymbol{X}_{i}$, where $\boldsymbol{X}$ and $\beta$ are the design matrix and the parameter vector, respectively.

Effect of $\log$ (area) only:

$$
\log \mu(S)=\beta_{0}+\beta_{1} \log _{10} A
$$


TABLE 1 Species composition recorded over time on reference islands in the Hauraki Gulf, New Zealand, that have never had predators.

\begin{tabular}{llll}
\hline & & Dates observed \\
Disturbance history & Seabird assemblages & breeding & Data source \\
\hline
\end{tabular}

\section{Tawhiti Rahi (155.9 ha; Poor Knights Islands)}

Crop cultivation \& seabird harvest (pre-

European); burning of the flat areas of the island

\section{Hongiora (15.55 ha; Aldermen Islands)}

Extensive burning of vegetation prior to 1935 muttonbird harvest by local Maori

\section{Ruamahuaiti (23.79 ha; Aldermen Islands)}

Pigs were present on the islands briefly in 1842 ,

but no records of how or when they were re-

moved; the impact on seabirds was likely to be minimal according to observations from

McFadden (1986)
Grey-faced petrel
Pterodroma gould

Pycroft's petrel

Pterodroma pycrofti

Fairy prion Pachyptila

turtur

Buller's shearwater

Ardenna bulleri

Fluttering shearwater

Puffinus gavia

Little shearwater Puffinus

assimilis kermadecensis

Common diving petrel

Pelecanoides urinatrix

White-faced storm petrel

Pelagodroma maoriana

Grey-faced petrel

Flesh-footed shearwater

Ardenna carneipes

Sooty shearwater Puffinus

griseus

White-faced storm petrel

Common diving petrel

Fluttering shearwater

Little shearwater

Little penguin Eudyptula

minor

Fairy prion

Grey-faced petrel

Fluttering shearwater

Little shearwater

Common diving petrel $1973,1981^{\star}, 2013$

$1973,1981^{\star}, 2013$

1946, 1973, 1976

$1981^{*}, 2013$

$1946,1973,1981^{\star}, 2013$

$1973,1981^{\star}, 2013$

$1973,1981^{\star}, 2013$

$1973,1981^{*}, 2013$

$1973,1981^{\star}, 2013$

1973,2013

1928,2013

1967, 2013

1928, 1973, 1986, 2013

$1958,1963,1973,2013$

2013

2013

2013

2013

1973,2013

1928, 1973, 2013

1967, 2013

1973, 2013
Veitch et al. (1973); McCallum (1981); this study \& P. Lyver, 2015, pers. comm.

Veitch et al. (1973); McCallum (1981); this study \& P. Lyver, 2015, pers. comm.

Buddle (1946); Veitch et al. (1973); Harper (1976); McCallum

(1981); this study \& P. Lyver, 2015, pers. comm.

Blackburn (1958); Veitch et al. (1973); McCallum (1981); this study \& P. Lyver, 2015, pers. comm.

Veitch et al. (1973); McCallum (1981); this study \& P. Lyver, 2015, pers. comm.

Veitch et al. (1973); McCallum (1981); this study \& P. Lyver, 2015, pers. comm

Veitch et al. (1973); McCallum (1981); this study \& P. Lyver, 2015, pers. comm.

Veitch et al. (1973); McCallum (1981); this study \& P. Lyver, 2015, pers. comm.

Fogarty \& Douglas (1973); this study \& P. Lyver, 2015, pers. comm Sladden \& Falla (1958); this study \& P. Lyver, 2015, pers. comm.

Adams (1967; cited in Fogarty \& Douglas, 1973); this study \& P. Lyver, 2015, pers. comm.

Sladden \& Falla (1958); Fogarty \& Douglas (1973); McFadden (1986); this study \& P. Lyver, 2015, pers. comm.

Blackburn (1958); Adams (1967; cited in Fogarty \& Douglas, 1973); Fogarty \& Douglas (1973); this study \& P. Lyver, 2015, pers. comm.

This study \& P. Lyver, 2015, pers. comm.

This study \& P. Lyver, 2015, pers. comm.

This study \& P. Lyver, 2015, pers. comm.

This study \& P. Lyver, 2015, pers. comm.

Fogarty \& Douglas (1973); this study \& P. Lyver, 2015, pers. comm. Sladden \& Falla (1958); Fogarty \& Douglas (1973); this study \& P. Lyver, 2015, pers. comm.

Adams (1967; cited in Fogarty \& Douglas, 1973); this study \&

P. Lyver, 2015, pers. comm.

Fogarty \& Douglas (1973); this study \& P. Lyver, 2015, pers. comm. 
Table 1 (Cont.)

\begin{tabular}{|c|c|c|c|}
\hline Disturbance history & Seabird assemblages & $\begin{array}{l}\text { Dates observed } \\
\text { breeding }\end{array}$ & Data source \\
\hline \multicolumn{4}{|c|}{ Ruamahuanui (32.4 ha; Aldermen Islands) } \\
\hline \multirow[t]{6}{*}{ Burned in the late $1800 \mathrm{~s}$} & Grey-faced petrel & $1972,1973,2013$ & $\begin{array}{l}\text { Merton et al. (1972); Fogarty \& Douglas (1973); this study \& } \\
\text { P. Lyver, 2015, pers. comm. }\end{array}$ \\
\hline & Fluttering shearwater & 1972,2013 & Merton et al. (1972); this study \& P. Lyver, 2015, pers. comm. \\
\hline & Little shearwater & 1972, 2013 & Merton et al. (1972); this study \& P. Lyver, 2015, pers. comm. \\
\hline & Sooty shearwater & 1928, 1972, 2013 & $\begin{array}{l}\text { Sladden \& Falla (1958); Merton et al. (1972); this study \& P. Lyver, } \\
\text { 2015, pers. comm. }\end{array}$ \\
\hline & Little penguin & 2013 & This study \& P. Lyver, 2015, pers. comm. \\
\hline & Common diving petrel & 2013 & This study \& P. Lyver, 2015, pers. comm. \\
\hline \multicolumn{4}{|l|}{ Middle (11 ha; Mercury Islands) } \\
\hline \multirow[t]{8}{*}{ Few signs of burning; undisturbed } & Grey-faced petrel: & $1962,1985,2013$ & $\begin{array}{l}\text { Skegg (1963); Atkinson (1964); Southey (1985); this study \& } \\
\text { P. Lyver, 2015, pers. comm. }\end{array}$ \\
\hline & Pycroft's petrel & $\begin{array}{l}1985 \text { (may not be } \\
\text { breeding), } 2013\end{array}$ & Southey (1985); this study \& P. Lyver, 2015, pers. comm. \\
\hline & Flesh-footed shearwater & $1962,1985,2013$ & $\begin{array}{l}\text { Skegg (1963); Atkinson (1964); Southey (1985); this study \& } \\
\text { P. Lyver, 2015, pers. comm. }\end{array}$ \\
\hline & Fluttering shearwater & $1962,1985,2013$ & $\begin{array}{l}\text { Atkinson (1964); Southey (1985); this study \& P. Lyver, 2015, pers. } \\
\text { comm. }\end{array}$ \\
\hline & Little shearwater & $1962,1985,2013$ & $\begin{array}{l}\text { Atkinson (1964); Southey (1985); this study \& P. Lyver, 2015, pers. } \\
\text { comm. }\end{array}$ \\
\hline & White-faced storm petrel & 1985,2013 & Southey (1985); this study \& P. Lyver, 2015, pers. comm. \\
\hline & Common diving petrel & $1962,1985,2013$ & $\begin{array}{l}\text { Atkinson (1962); Skegg (1963); Southey (1985); this study \& } \\
\text { P. Lyver, 2015, pers. comm. }\end{array}$ \\
\hline & Little penguin & $1962,1985,2013$ & $\begin{array}{l}\text { Skegg (1963); Atkinson (1964); Adams (1967; cited in Fogarty \& } \\
\text { Douglas, 1973); Atkinson (1964) }\end{array}$ \\
\hline \multicolumn{4}{|l|}{ Green (2.5 ha; Mercury Islands) } \\
\hline \multirow[t]{7}{*}{ Few signs of burning; undisturbed } & Grey-faced petrel & 1962, 1967, 2013 & $\begin{array}{l}\text { Skegg (1963); Atkinson (1964); Thoresen (1967); this study \& } \\
\text { P. Lyver, 2015, pers. comm. }\end{array}$ \\
\hline & Common diving petrel & $1962,1967,2013$ & $\begin{array}{l}\text { Atkinson (1962); Skegg (1963); Thoresen (1967); this study \& } \\
\text { P. Lyver, 2015, pers. comm. }\end{array}$ \\
\hline & Flesh-footed shearwater & $1962,1967,2013$ & $\begin{array}{l}\text { Atkinson (1964); Thoresen (1967); this study \& P. Lyver, 2015, pers. } \\
\text { comm. }\end{array}$ \\
\hline & Fluttering shearwater & $1962,1967,2013$ & $\begin{array}{l}\text { Skegg (1963); Thoresen (1967); this study \& P. Lyver, 2015, pers. } \\
\text { comm. }\end{array}$ \\
\hline & Little shearwater & $1962,1967,2013$ & $\begin{array}{l}\text { Skegg (1963); Atkinson (1964); Thoresen (1967); this study \& } \\
\text { P. Lyver, 2015, pers. comm. }\end{array}$ \\
\hline & White-faced storm petrel & 1967, 2013 & Thoresen (1967); this study \& P. Lyver, 2015, pers. comm. \\
\hline & Little penguin & $1962,1967,2013$ & $\begin{array}{l}\text { Atkinson (1964); Thoresen (1967); this study \& P. Lyver, 2015, pers. } \\
\text { comm. }\end{array}$ \\
\hline
\end{tabular}

${ }^{*}$ McCallum (1981) noted that seabirds that were recorded on the island previously were not present on his visit in 1981 because it did not coincide with the breeding times of these birds. (1981 not confirmed breeding). 
Additive effects of $\log ($ area) and predator status (i.e. separate intercept per predator status but same slope):

$$
\log \mu(S)=\beta_{0}+\beta_{1} \log _{10} A+\beta_{2} \text { Predator }
$$

Interaction of $\log ($ area $)$ and predator status (i.e. separate slope and intercept per predator status):

$$
\log \mu(S)=\beta_{1} \text { Predator }+\beta_{2} \log _{10} A \times \text { Predator }
$$

Multi-model inference based on Poisson generalized linear models was used to explore possible predictors of species richness for the cleared islands (Burnham \& Anderson, 2002). The predictors explored were size, time since eradication, distance to the mainland (i.e. the nearest point on the coastline of the North Island) and distance to Auckland city centre $\left(36.85^{\circ} \mathrm{S}, 174.76^{\circ} \mathrm{E}\right)$, the latter two being potential proxies for human disturbance and/or distance to offshore feeding grounds. Distances were calculated using the rgeos package (Bivand \& Rundel, 2016). We used the MuMIn package (Bartoń, 2015) to generate a complete set of candidate models based on the above predictors, and ranked the resulting model fits by Akaike information criterion corrected for a small sample size (AICc).

We used $\chi^{2}$ tests $(\alpha=0.05)$ of frequency of occurrence to evaluate the differences in species present on cleared, uninvaded and invaded islands (R Development Core Team, 2013). Given the poor representation or absence of some species within island categories, analyses used a subset of six widely distributed species (Fig. 3).

We used a Kruskal-Wallis rank sum test to test for differences in the mean age at first reproduction, a possible proxy for colonization ability, for each island assemblage. Species-specific values (Supplementary Table S2) were averaged over all breeding species on a given island.

\section{Results}

The mean area of uninvaded islands was $13.88 \pm$ SD 31.43 ha (range 1.04-155.92 ha), biased towards $<10$ ha ( 23 of 30 islands). The mean area of invaded islands was $24.79 \pm \mathrm{SD}$ 62.34 ha (range 1.14-312.33 ha). The mean area of cleared islands was $286.15 \pm$ SD 675.7 ha (range $1-2,817 \mathrm{ha}$ ), and represented the most evenly spread area range of all three categories.

The final model for the species-area relationship included separate slopes and intercepts by predator status. No significant overdispersion was detected (overdispersion test: dispersion parameter $=0.99 ; \quad \mathrm{P}=0.53)$. Moran's I $(\mathrm{I}=0.1, \mathrm{P}=0.011)$ indicated weak but statistically significant spatial autocorrelation in the residuals, and visual inspection of spatial residuals indicated that this was because the model overpredicted species richness for the islands of the inner Hauraki Gulf (Supplementary Fig. S1). Generalized linear model parameter estimates are in Table 2, and model predictions are illustrated in Fig. 2.

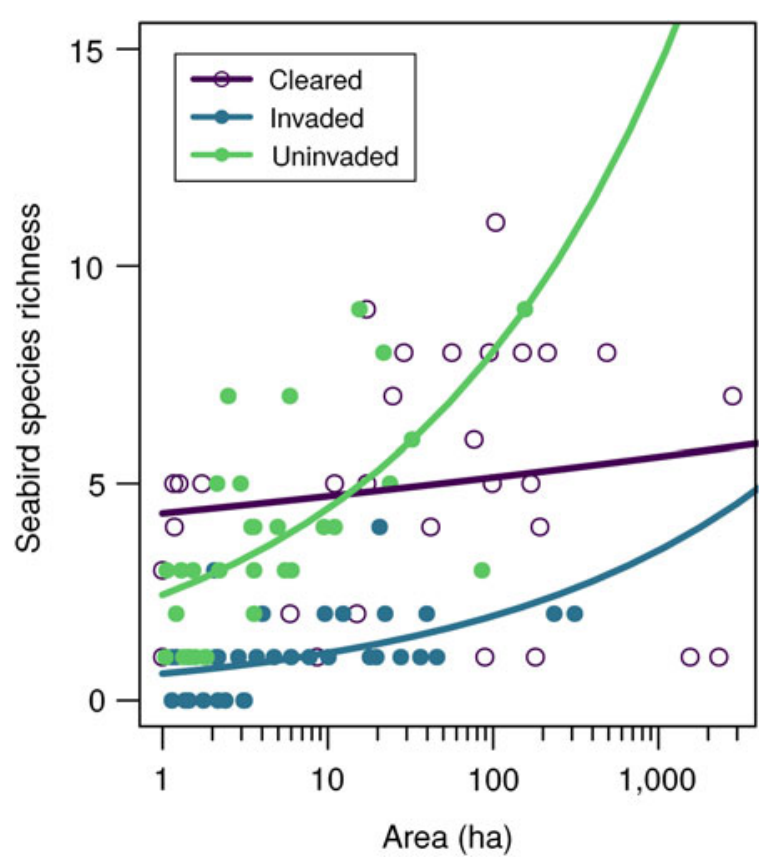

FIG. 2 Observed species richness and generalized linear model predictions as a function of island area for uninvaded (intercept $=2.43$, slope $=0.26$ ), cleared $($ intercept $=4.31$, slope $=0.04)$, and invaded islands (intercept $=0.62$, slope $=0.25$ ) in the Hauraki Gulf (Fig. 1). Model parameter estimates are in Table 2.

TABLE 2 Generalized linear model parameter estimates for the species-area relationship by predator status. Parameter values are given on the link scale.

\begin{tabular}{lrr}
\hline & \multicolumn{1}{l}{$\begin{array}{l}\text { Parameter } \\
\text { estimate } \pm \text { SE }\end{array}$} & \multicolumn{1}{c}{ P } \\
\hline Parameter & $1.462 \pm 0.160$ & $<0.001$ \\
Predator_statusCleared & $-0.480 \pm 0.285$ & 0.092 \\
Predator_statusInvaded & $0.890 \pm 0.156$ & $<0.001$ \\
$\log ($ ha):Predator_statusCleared & $0.038 \pm 0.036$ & 0.295 \\
$\log ($ ha):Predator_statusInvaded & $0.249 \pm 0.096$ & 0.009 \\
$\log ($ ha):Predator_statusUninvaded & $0.259 \pm 0.062$ & $<0.001$ \\
\hline
\end{tabular}

For uninvaded islands the intercept (i.e. expected species count on a 1 ha island) is 2.43 (95\% CI 1.77-3.28; $\hat{\beta}=0.89$, $\mathrm{P}<0.001$ ), and for a 10-fold increase in area the species count is expected to increase 1.81-fold (95\% CI 1.36-2.39; $\hat{\beta}=0.26, \mathrm{P}<0.001)$. For cleared islands the intercept is 4.31 (95\% CI 3.12-5.84; $\hat{\beta}=1.46, \mathrm{P}<0.001$ ), and no significant relationship was found between species richness and area $(\hat{\beta}=0.04, \mathrm{P}=0.295)$. For invaded islands the intercept is $0.62(95 \% \mathrm{CI} 0.34-1.05 ; \hat{\beta}=-0.48, \mathrm{P}=0.092)$, and for $\mathrm{a}$ 10 -fold increase in area the species count is expected to increase 1.77 -fold (95\% CI 1.14-2.71; $\hat{\beta}=0.25, \mathrm{P}=0.009$ ). Regardless of size, invaded islands did not have more than four species (Fig. 2). 

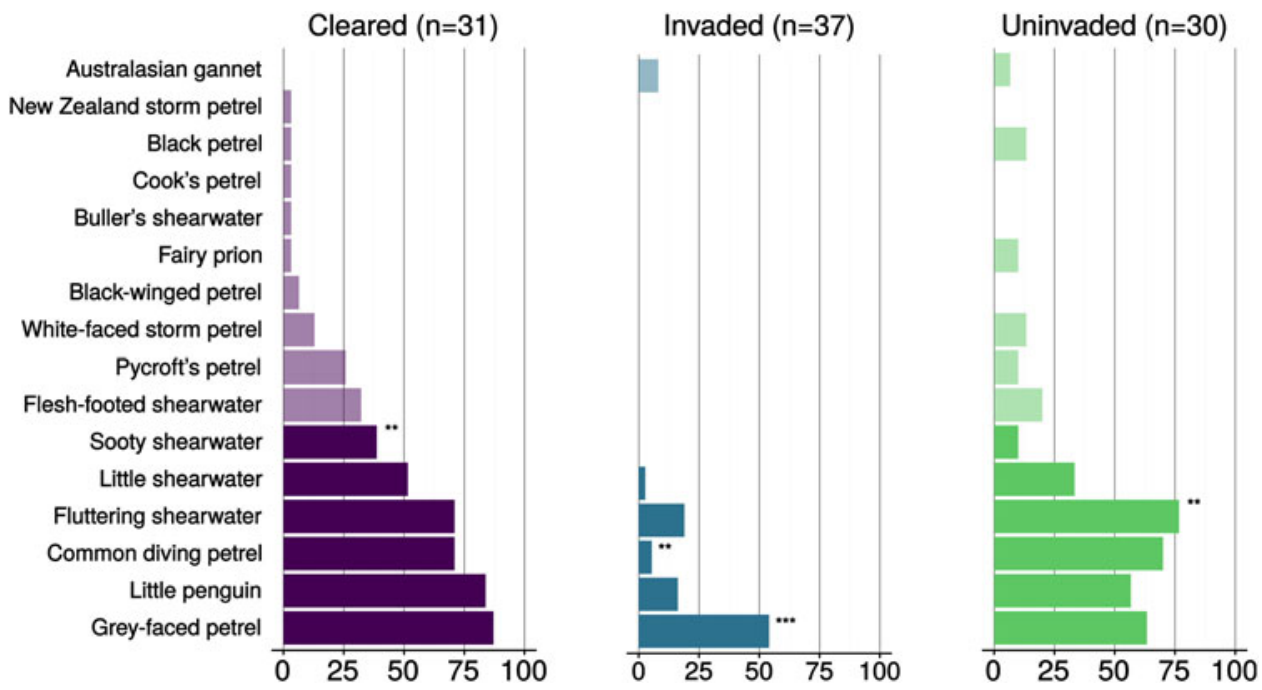

FIG. 3 Percentage of cleared, uninvaded and invaded islands in the wider Hauraki Gulf region, New Zealand (Fig. 1) on which seabird species were confirmed to be breeding. The darker bars indicate the data met the assumptions of the $\chi^{2}$ test. Bias was towards areas $<10$ ha and $>155$ ha on uninvaded and invaded islands, respectively. ${ }^{\star} \mathrm{P}<0.1$, ${ }^{* *} \mathrm{P}<0.05,{ }^{* \star *} \mathrm{P}<0.01$.

The largest suite of species included in the analysis was on cleared islands, with the smallest on invaded islands (Fig. 3). Standard residuals from the $\chi^{2}$ test showed a higher than expected proportion of invaded islands with grey-faced petrels $(\mathrm{P}=0.001, \mathrm{df}=12$, standard residual $=4.66)$. A higher than expected proportion of cleared islands had sooty shearwaters $(\mathrm{P}=0.023$, standard residual $=2.39)$, and a higher than expected proportion of uninvaded islands had fluttering shearwaters Puffinus gavia $(\mathrm{P}=0.033$, standard residual $=1.52$ ). On invaded islands there were fewer than expected populations of common diving petrels Pelecanoides urinatrix $(\mathrm{P}=0.027$, standard residual $=-1.92)$. Seven species of seabirds present on cleared and/or uninvaded islands were absent from invaded islands (Fig. 3).

Multi-model inference did not provide strong evidence for a link between the time since eradication and species richness. Distance to Auckland was retained as a predictor in all six models that were within 3 AICc units of the optimal model, with higher species richness on islands further from the city. Distance to mainland and island size were each retained in three of the top six models, but effect sizes were close to zero when both predictors were retained in the same model. Island size had a positive effect on species richness, whereas distance to mainland had a negative effect (Table 3; Supplementary Fig. S4).

On the reference islands, species composition was stable for up to 85 years (Table 1 ). No species identified in early reports had disappeared from any island. In one group (Ruamaahua) up to four species not recorded previously were present in 2013 (Table 1).

\section{Discussion}

Eradicating invasive predators facilitates the recovery of resident seabird populations, and recolonization by species that have been extirpated (Kappes \& Jones, 2014). According to the equilibrium theory of island biogeography, area should be the best predictor of species richness on islands (Preston, 1962; MacArthur \& Wilson, 1967). In our analysis we assumed that species richness of seabirds on cleared islands should resemble, or begin to resemble, that of uninvaded islands of a comparable area within a similar biogeographical region. Despite our data undoubtedly being influenced by variable survey effort, and temporal and spatial biases such as island size and a lack of pre-invasion census data, seabirds are recolonizing cleared islands in the Hauraki Gulf (Fig. 2). This recolonization is promising, especially as all of the species absent from invaded islands are now breeding on cleared islands (Fig. 3). Furthermore, the uninvaded islands Hongiora and Ruamahuanui appear to have recruited species that had not been observed there previously (Table 1), perhaps as spillover from populations increasing elsewhere as a part of natural assemblage equilibrium processes (C. Gaskin, unpubl. data; Simberloff, 1974; Buxton et al., 2016). Although varying rates of recolonization and local extinction may result in a species richness rebound effect following the removal of predators (Cirtwill \& Stouffer, 2016), ecological diversity is likely to exert a strong influence on the return of seabird assemblages to equilibrium on cleared islands (Preston, 1962; MacArthur \& Wilson, 1967; Simberloff, 1974). We posit that within our case study system the seabird assemblage structure on cleared islands probably reflects the effects of five components: (1) spatial distribution of islands influencing proximity to source populations, foraging areas and/or human activities; (2) time since eradication; (3) behavioural influences, including interspecific interactions; (4) the availability of suitable habitats; and (5) the colonizing ability of individual species (Fig. 4). Our statistics support the influence of space (1) and, to a lesser extent, time (2). However, our model was not able to explain all of the variance. The literature provides some guidance for the behavioural (3), 


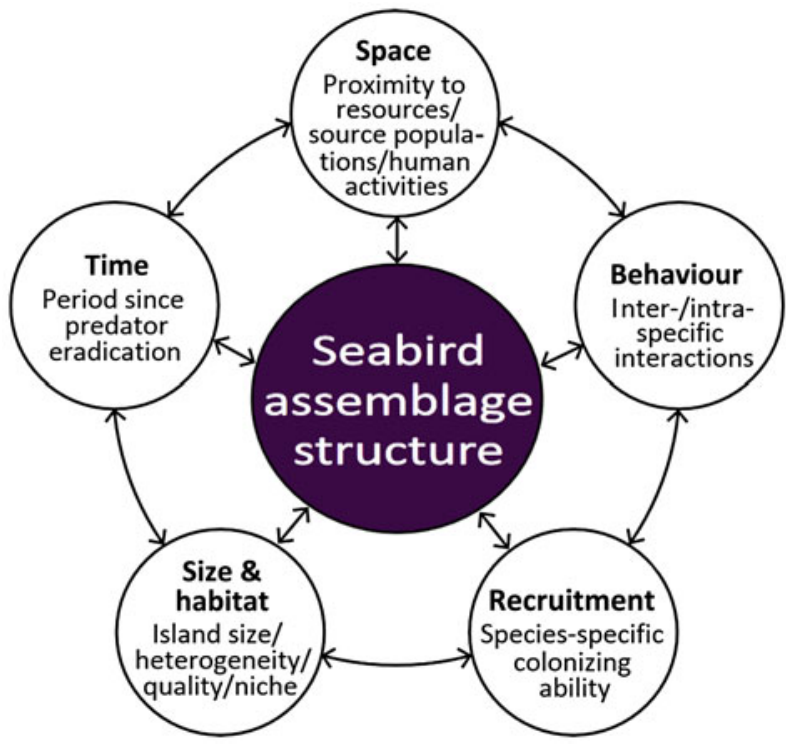

FIG. 4 Schematic representation of the key influences on seabird recolonization of islands cleared of predators.

within habitat (4), and demographic (5) influences on seabird recolonization to islands cleared of invasive predators in the Hauraki Gulf.

\section{Space}

The rate and pattern of seabird recovery appear to be most influenced by the proximity of cleared islands to source populations, foraging areas and/or human activities. Distance to local populations was the strongest influence on seabird recruitment in the study of Buxton et al. (2014), where the natural recolonization response fell below $50 \%$ when the source population was $\geq 25 \mathrm{~km}$ from the recruitment site. Borrelle et al. (2015) found lower than expected species richness on Hauraki Gulf islands beyond the $25 \mathrm{~km}$ radius, thus supporting distance to source populations as a key driver of passive seabird recolonization (Buxton et al., 2014). Regarding proximity to foraging grounds, the ideal situation for species is the juxtaposition of resources that reduces costs to the individual (Estades, 2001). Seabirds represent the extreme end of these habitat-resource spatial patterns, with foraging grounds often at considerable distances from breeding sites, and distributed discontinuously across space and time (Estades, 2001). The disparity between breeding sites and the dynamic nature of foraging areas means that these relationships are not well understood (Fernández-Chacón et al., 2013). Although we found no compelling evidence of spatial correlation, we note that islands located in the Inner Gulf all had negative residuals (Supplementary Fig. S1). This may be explained by the results from multi-model inference, which suggested that proximity to Auckland negatively influenced the spatial distribution of seabird recovery (Table 3; Supplementary

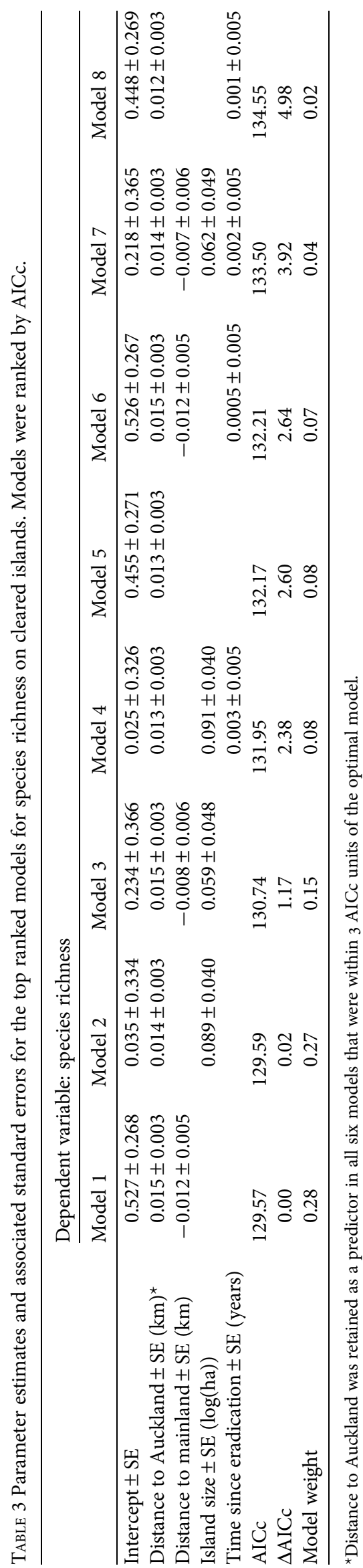


Fig. S4). This could be attributed to a combination of proximity to source populations, optimal foraging theory, and greater habitat modification and marine activity, such as commercial and recreational fisheries, and shipping, in these areas (Borrelle, 2013; Gaskin \& Rayner, 2013). More detailed evaluation of effect modifiers in relation to proximity to human activities and foraging patterns (e.g. using detailed telemetry data) may improve the predictability of the model.

\section{Time}

A positive but statistically non-significant increase in species richness was observed with time since eradication. This result may be influenced by a strong temporal artefact because our analysis of seabird recovery on some islands reflects predator eradication carried out c. 20 years ago (Supplementary Fig. S2). Our comparisons of species richness with island area indicate that not all cleared islands have a similar level of seabird richness to uninvaded islands of comparable size. This may indicate that there has been insufficient time for the recolonization of seabirds to those islands, particularly on larger islands that were cleared more recently following the resolution of logistical and operational challenges (Towns \& Broome, 2003). Variations in the speed and/or capacity of individual species to recolonize may also be a contributing factor. However, given the generalized linear model predictions of species richness on cleared islands compared to invaded islands it appears that on many cleared islands species richness has increased following eradication of predators (Fig. 2). On some islands these responses have been rapid and unpredicted; for example, Burgess Island has seen the recovery of seven species of Procellariiformes (Table 4; Ismar et al., 2014). Furthermore, since the eradications of cats (1970s) and kiore (2004) on Te-Hauturu-o-Toi (Little Barrier Island), the New Zealand storm petrel has reached sufficient numbers for identification of a breeding population of this species, which was hitherto presumed to be extinct (Rayner et al., 2015). Cirtwill \& Stouffer (2016) found that species richness on disturbed mangrove islands increased temporarily once the disturbance (predation) was removed. Species assemblages then stabilized, with equilibrium between immigration and extirpation (Cirtwill \& Stouffer, 2016). A similar process may be operating on some of our study islands, following predator eradication. However, little is known about the temporal dynamics of seabird communities during recolonization of islands. In the case of the volcanic island of Surtsey, in Iceland, nine seabird species established breeding sites successively over the course of 55 years. Only one of these, the Arctic tern Sterna paradisaea, failed to establish a permanent presence and went locally extinct after three breeding attempts across 4 years (Petersen, 2009).

\section{Behaviour}

Examples of intrinsic effects on seabird recovery can include situations where intra- and interspecific interactions exert strong influences on recovery rate and recruitment (Danchin et al., 1998; Parejo et al., 2005; Buxton et al., 2014). Recruitment to new breeding sites may be limited by the number of immature individuals in local metapopulations; because of the life history traits of seabirds, colony growth can be slow (Parejo et al., 2005). Also, the recruitment of immature individuals is influenced by the availability of suitable habitat and social cues (Danchin et al., 1998; Parejo et al., 2005). These interactions can influence breeding success or immigration rates as a result of limited access to nest sites. Passive recolonization of seabirds on 92 offshore islands in New Zealand following the removal of introduced predators was greater where more than two seabird species were present (Buxton et al., 2014), probably because of a conspecific attraction to preferential habitat (Danchin et al., 1998; Parejo et al., 2005; Buxton et al., 2014). In contrast, numbers of greyfaced petrels appeared to decline on the Poor Knights Islands as Buller's shearwaters increased in abundance, even though grey-faced petrels are abundant on Taranga Island in the neighbouring Hen and Chickens group (Harper, 1983). Interspecific competition may play a greater role than predator presence in the distribution of greyfaced petrels on the Poor Knight's group, given the higher than expected proportion of invaded islands where this species is present (Fig. 3).

TABLE 4 Seabird species assemblage on Burgess Island prior to rat eradication in 1990 (McCallum, 1980) and post-eradication (Ismar et al., 2014).

\begin{tabular}{llll}
\hline Species & Prior to rat eradication & Oct. 2010 & Sep. 2011 \\
\hline Australasian gannet Morus serrator & $\bullet$ & $\bullet$ & $\bullet$ \\
Grey-faced petrel & & $\bullet$ & $\bullet$ \\
Common diving petrel & $\bullet$ & $\bullet$ \\
Little shearwater & $\bullet$ & $\bullet$ \\
Fluttering shearwater & $\bullet$ & $\bullet$ \\
Sooty shearwater & $\bullet$ & $\bullet$ \\
White-faced storm petrel & & $\bullet$ \\
Black-winged petrel Pterodroma nigripennis & & $\bullet$ \\
\hline
\end{tabular}




\section{Size \& habitat}

We found that five of the 16 seabird species included in our analyses were absent from uninvaded islands (Fig. 3), whereas we found the full suite of species across cleared islands, which indicates rapid recolonization by seabirds following a release from predation pressure (Cirtwill \& Stouffer, 2016), and/or area-related limitations on ecological diversity influencing the availability of suitable habitat (Simberloff, 1974). Larger invaded islands may also serve as refugia for some species, despite the presence of predators, because of the availability of preferred habitat. For example, Cook's petrels and black petrels were not represented on uninvaded islands; however, both species were present on invaded and cleared islands. Cook's petrel was widely distributed on the mainland of New Zealand before the introduction of mammals (Imber et al., 2003b) but is now restricted to only three breeding sites: Codfish Island (southern New Zealand), Aotea (Great Barrier) and Te-Hauturu-o-Toi (Towns, 2009). Nest burrows are found in tall forests, generally $>250 \mathrm{~m}$ elevation on the latter two islands, suggesting climate could also play a role in this species' habitat preferences, with the largest population on predator-free $\mathrm{Te}$ Hauturu-o-Toi (estimated 286,00o breeding pairs in 2007; Rayner et al., 2007). Similarly, black petrels were once more widely distributed, breeding at five or more sites on the North Island before 1900 (Imber et al., 2003a). Black petrels are now restricted to Te-Hauturu-o-Toi and Aotea (estimated 2,00o breeding pairs; E. Bell, Wildlife Management International Ltd, pers. comm., 2015), also in colonies largely restricted to high-altitude $(>400 \mathrm{~m})$ tall forest (Francis \& Bell, 2010; Bell et al., 2012). For species such as Cook's and black petrels, habitat suitability and a lack of islands of sufficient size or elevation within their preferential climate envelope may be limiting factors in recruitment to newly predator-free sites. Conversely, more generalist species, such as grey-faced petrels, common diving petrels and fluttering shearwaters, may be less constrained by habitat suitability (Buxton et al., 2016).

\section{Recruitment}

We found that the proportion of islands with fluttering shearwaters was greatest for uninvaded islands (Fig. 3). Given that fluttering shearwaters are abundant in the region (estimated population of 20,000 pairs; C. Gaskin, unpubl. data), we might expect this species to be more widely distributed on cleared islands, as was found for sooty shearwaters, which have an estimated population of $<800$ pairs (Fig. 3; C. Gaskin, unpubl. data). Their contrary distribution suggests that fluttering shearwaters may have a more limited capacity for recruitment to new breeding sites than species such as the sooty shearwater. Behavioural or sex differences between species may also influence recruitment rates
(Dittmann et al., 2007) but there is limited understanding about how these influences may affect recruitment. Additional demographic traits, such as age at first breeding, may influence the species-specific rate of recovery (Nur \& Sydeman, 1999), where species that have shorter pre-breeding states may recolonize more quickly. On the Mokohinau Islands, for example, populations of common diving petrels and white-faced storm petrels Pelagodroma maoriana increased dramatically in the 2 decades following the removal of R. exulans (Ismar et al., 2014). For these two species the age at first reproduction is 2 or 3 years, compared to 5-10 years for black petrels and Pycroft's petrels Pterodroma pycrofti (New Zealand Birds Online, 2015). Mean assemblage age at first reproduction was lowest on invaded islands and highest on uninvaded islands, but these differences were not statistically significant (Kruskal-Wallis rank sum test, $\chi^{2}=5.72, \mathrm{df}=2, \mathrm{P}=0.057$; Supplementary Fig. S3a). Furthermore, across cleared islands the mean assemblage age at first reproduction increased with time since eradication, although again this result was not statistically significant (ordinary least squares regression, $\hat{\beta}=0.013$, $\mathrm{P}=0.20$; Supplementary Fig. S3b). Although we found no statistical evidence of age at first reproduction influencing recolonization potential in our study, the effect of age at first reproduction could have been masked by the small sample size, the relative recency of most eradications, and/ or the lack of time-series observations of the recovery process on individual islands. Further research may provide insight into relationships between recovery rate and age at first reproduction.

\section{Conclusion}

Predator eradication is an effective conservation tool for protecting and enhancing seabird colonies (Jones, 2010; Towns et al., 2013; Jones et al., 2016). Such actions can result in fundamental changes to the structure and species richness of island seabird faunas; however, we also found that once assemblages form they undergo little change over many decades despite pervasive extrinsic influences, such as fisheries bycatch and marine pollution. Nonetheless there are numerous constraints on natural recolonization; for example, despite their mobility over water, seabirds rarely establish new breeding sites, because of K-selected traits (Schreiber \& Burger, 2001; Hamer et al., 2002), although some seabird colonies are influenced by emigration and immigration and thus are not closed (Igual et al., 2007; Lawrence et al., 2014). Demographic, intrinsic, extrinsic, habitat and spatial factors also complicate seabird recovery following predator eradications, with additional variation caused by strong species- and site-specific effects (e.g. Buxton et al., 2014). Given the complex influences on recolonization, seabird conservation efforts that involve 
eradication of invasive species should aim to improve understanding of the species-specific and external effects on demographic traits and population dynamics, as these may elicit responses peculiar to regional faunas. To achieve this, effective and consistent monitoring plans should be an integral component of any seabird island restoration project.

\section{Acknowledgements}

We thank all the dedicated bird counters who contributed to this dataset, and those staff that contributed to the successful eradication of predators from the islands in the Hauraki Gulf and New Zealand. SBB was partially supported by the Todd Foundation. PHBS was supported by the U.S. National Science Foundation (Grant PLR-1341649). We also thank H.P. Jones and two anonymous reviewers for their thorough and useful comments.

\section{Author contributions}

SBB and DRT conceived and designed the study. DRT and CPG provided the data and SBB and PHBS analysed data. All authors wrote and edited the manuscript.

\section{References}

Ad a ms, G.P. (1967) Island survey form. In Fogarty, S.M. \& Douglas, M. E. (1973) The birds of the Aldermen Islands, Tane, 19, 31-39.

AtKinson, I.A.E. (1962) Report on the Vegetation of the Smaller Mercury Islands and Ohena Island. Unpublished report.

AtKinson, I.A.E. (1964) The flora, vegetation, and soils of Middle and Green Islands, Mercury Islands group. New Zealand Journal of Botany, 2, 385-402.

Baillie, J.E., Hilton-Taylor, C. \& Stuart, S.N. (2004) 2004 IUCN Red List of Threatened Species: A Global Species Assessment. IUCN, Gland, Switzerland.

B ARTON, K. (2015) MuMIn: Multi-Model Inference. R package version 1.15.1. Http://CRAN.R-project.org/package=MuMIn.

Bell, E.A., Sim, J.L., Scofield, P., Francis, C. \& NIWA (2012) Population Parameters of the Black Petrels (Procellaria parkinsoni) on Great Barrier Island (Aotea Island), 2009/1o. Unpublished report prepared for the Department of Conservation, Wellington, New Zealand.

Birdife International (2015) Taxonomy. Http://www.birdlife. org/datazone/info/taxonomy [accessed 14 April 2015].

Bivand, R.S., Pebesma, E. \& Gomez-Rubio, V. (2013) Applied Spatial Data Analysis with R. 2nd edition. Springer, New York, USA.

BIVAND, R.S. \& RUNDEL, C. (2016) rgeos: Interface to Geometry Engine - Open Source (GEOS). R package version o.3-19. Http:// CRAN.R-project.org/package $=$ rgeos.

BLACKBURN, A. (1958) Island survey form. In Fogarty, S.M. \& Douglas, M.E. (1973) The birds of the Aldermen Islands. Tane, 19, 31-39.

Borrelle, S.B. (2013) Recovery and re-colonisation of seabirds on islands in the Hauraki Gulf after pest eradication. BSc thesis. Auckland University of Technology, Auckland, New Zealand.
Borrelle, S.B., Buxton, R.T., Jones, H.P. \& Towns, D.R. (2015) A GIS-based decision-making approach for prioritizing seabird management following predator eradication. Restoration Ecology, 23, 580-587.

Buddle, G.A. (1946) A second visit to the Poor Knights. Emu, 45, 315-318.

Burnham, K.P. \& Anderson, D.R. (2002) Model Selection and Multimodel Inference: A Practical Information-Theoretic Approach. 2nd edition. Springer-Verlag, New York, USA.

Burns, K.C., McHardy, R.P. \& Pledger, S. (2009) The small-island effect: fact or artefact? Ecography, 32, 269-276.

Buxton, R.T., Jones, C.J., Moller, H. \& Towns, D.R. (2014) Drivers of seabird population recovery on New Zealand islands after predator eradication. Conservation Biology, 28, 333-344.

Buxton, R.T., Taylor, G., Jones, C.P., Lyver, P.O., Moller, H., Cree, A. \& Towns, D.R. (2016) Spatio-temporal changes in density and distribution of burrow-nesting seabird colonies after rat eradication. New Zealand Journal of Ecology, 40, 88-99.

Cirtwill, A.R. \& Stouffer, D.B. (2016) Knowledge of predator-prey interactions improves predictions of immigration and extinction in island biogeography. Global Ecology and Biogeography, 25, 900-911.

CliFlo (2016) New Zealand National Climate Database. Http://cliflo. niwa.co.nz/ [accessed 18 November 2015].

Croxall, J.P., Butchart, S.H.M., Lascelles, B., Stattersfield, A. J., Sullivan, B., Symes, A. \& TAylor, P. (2012) Seabird conservation status, threats and priority actions: a global assessment. Bird Conservation International, 22, 1-34.

Danchin, E., Boulinier, T. \& Massot, M. (1998) Conspecific reproductive success and breeding habitat selection: implications for the study of coloniality. Ecology, 79, 2415-2428.

Dittmann, T., Ezard, T.H. \& Becker, P.H. (2007) Prospectors' colony attendance is sex-specific and increases future recruitment chances in a seabird. Behavioural Processes, 76, 198-205.

DuFFy, D. C. (1994) Afterwards: An agenda for managing seabirds and islands. In Seabirds on Islands: Threats, Case Studies and Action Plans (eds D.N. Nettleship, J. Burger \& M. Gochfeld), pp. 311-318. BirdLife International, Cambridge, UK.

Estades, C.F. (2001) The effect of breeding-habitat patch size on bird population density. Landscape Ecology, 16, 161-173.

Fernández-Chacón, A., Genovart, M., Pradel, R., Tavecchia, G., Bertolero, A., Piccardo, J. et al. (2013) When to stay, when to disperse and where to go: survival and dispersal patterns in a spatially structured seabird population. Ecography, 36, 1117-1126.

Fogarty, S.M. \& Douglas, M.E. (1973) The birds of the Aldermen Islands. Tane, 19, 31-39.

Francis, R.I.C.C. \& Bell, E.A. (2010) Fisheries Risks to the Population Viability of Black Petrel (Procellaria parkinsoni). New Zealand Aquatic Environment and Biodiversity Report No. 51. Ministry of Fisheries, Wellington, New Zealand.

Furness, R.W. \& Camphuysen, K.C. (1997) Seabirds as monitors of the marine environment. ICES Journal of Marine Science, 54, 726-737.

Gaskin, C. (2012) Seabirds of the Kermadec Region: Their Natural History and Conservation. Unpublished report. Department of Conservation, Wellington, New Zealand.

Gaskin, C., Fitzgerald, N., Cameron, E.K. \& Heiss-Dunlop, S. (2011) Does the New Zealand storm petrel (Pealeornis maoriana) breed in northern New Zealand? Notornis, 58, 104-112.

Gaskin, C. \& Rayner, M.J. (2013) Seabirds of the Hauraki Gulf: Natural History, Research and Conservation. Unpublished report. Hauraki Gulf Forum, Auckland, New Zealand.

GAzE, P. (2000) The response of a colony of sooty shearwater (Puffinus griseus) and flesh-footed shearwater (P. carneipes) to the cessation of harvesting and the eradication of Norway rats (Rattus norvegicus). New Zealand Journal of Zoology, 27, 375-379. 
Hamer, K.C., Schreiber, E. \& Burger, J. (2002) Breeding biology, life histories, and life history-environment interactions in seabirds. In Biology of Marine Birds (eds E.A. Schreiber \& J. Burger), pp. 217262. CRC Press, Boca Raton, USA.

HARPER, P. (1976) Breeding biology of the fairy prion (Pachyptila turtur) at the Poor Knights Islands, New Zealand. New Zealand Journal of Zoology, 3, 351-371.

HARPER, P. (1983) Biology and Conservation of the Buller's Shearwater (Puffinus bulleri) at the Poor Knights Islands, New Zealand. Unpublished report. Northern Offshore Islands Symposium, Auckland, New Zealand.

Harris, M.P. (1970) The biology of an endangered species, the darkrumped petrel (Pterodroma phaeopygia), in the Galapagos Islands. The Condor, 72, 76-84.

Igual, J.M., Forero, M.G., Gomez, T. \& Oro, D. (2007) Can an introduced predator trigger an evolutionary trap in a colonial seabird? Biological Conservation, 137, 189-196.

Imber, M.J., McFadden, I., Bell, E.A. \& Scofield, P.R. (2003a) Post-fledging migration, age of first return and recruitment, and results of inter-colony translocation of black petrels (Procellaria parkinsoni). Notornis, 50, 183-19o.

Imber, M.J., West, J.A. \& CoOper, W.J. (2003b) Cook's petrel (Pterodroma cookii): historic distribution, breeding biology and effects of predators. Notornis, 50, 221-230.

Island Conservation and Invasive Species Specialist Group (2015) Database of Island Invasive Species Eradications. Http://diise. islandconservation.org/ [accessed 3 July 2015].

Ismar, S.M., B AIRD, K.A., GAskin, C.P., TAylor, G.A., Tennyson, A.J., RAYNER, M.J. et al. (2014) A case of natural recovery after the removal of invasive predators-community assemblage changes in the avifauna of Burgess Island. Notornis, 61, 188-195.

IUCN (2015) IUCN Red List of Threatened Species v. 2014.1. Http:// www.iucnredlist.org [accessed 5 March 2016].

Jones, H.P. (2010) Prognosis for ecosystem recovery following rodent eradication and seabird restoration in an island archipelago. Ecological Applications, 20, 1204-1216.

Jones, H.P., Holmes, N.D., Butchart, S.H.M., Tershy, B.R., KAPpes, P.J., Corkery, I. et al. (2016) Invasive mammal eradication on islands results in substantial conservation gains. Proceedings of the National Academy of Sciences of the United States of America, 113, 4033-4038.

Jones, H.P. \& KRess, S.W. (2012) A review of the world's active seabird restoration projects. The Journal of Wildlife Management, $76,2-9$.

Jones, H.P., Tershy, B.R., Zavaleta, E.S., Croll, D.A., Keitt, B.S., Finkelstein, M.E. \& Howald, G.R. (2008) Severity of the effects of invasive rats on seabirds: a global review. Conservation Biology, 22, 16-26.

Jones, H.P., Towns, D.R., Bodey, T., Miskelly, C.M., Ellis, J., RAUZON, M.J. et al. (2011) Recovery and restoration on seabird islands. In Seabird Islands: Ecology, Invasion, and Restoration (eds C.P. Mulder, W. Anderson, D.R. Towns \& P. Bellingham), pp. 317357. Oxford University Press, Oxford, UK.

KAPPES, P.J. \& JONES, H.P. (2014) Integrating seabird restoration and mammal eradication programs on islands to maximize conservation gains. Biodiversity and Conservation, 23, 503-509.

Kleiber, C. \& Zeileis, A. (2008) Applied Econometrics with $R$. Springer-Verlag, New York, USA.

Lavers, J.L., Wilcox, C. \& Donlan, C.J. (2010) Bird demographic responses to predator removal programs. Biological Invasions, 12, 3839-3859.

Lawrence, H.A., Lyver, P.O.B. \& Gleeson, D.M. (2014) Genetic panmixia in New Zealand's grey-faced petrel: implications for conservation and restoration. Emu, 114, 249-258.
Le Corre, M., Danckwerts, D.K., Ringler, D., Bastien, M. Orlowski, S., Rubio, C.M. et al. (2015) Seabird recovery and vegetation dynamics after Norway rat eradication at Tromelin Island, western Indian Ocean. Biological Conservation, 185, 85-94.

Le Corre, M., Ollivier, A., Ribes, S. \& Jouventin, P. (2002) Lightinduced mortality of petrels: a 4-year study from Réunion Island (Indian Ocean). Biological Conservation, 105, 93-102.

MacArthur, R.H. \& Wilson, E.O. (1967) The Theory of Island Biogeography. Princeton University Press, Princeton, USA.

McCallum, J. (1980) The birds of the Northern Mokohinau Group. Tane, 26, 69-78.

McCallum, J. (1981) Birds of Tawhiti Rahi Island, Poor Knights Group, Northland, New Zealand. Tane, 27, 59-66.

McFadden, I. (1986) Aldermen Islands. Unpublished report.

Medway, D.G. (2001) Pigs and petrels on the Poor Knights islands. New Zealand Natural Sciences, 26, 87-90.

Merton, D., Crook, I., Whitaker, A. \& Ramsay, G. (1972) Island survey form. Unpublished surveys.

Monaghan, P. (1996) Relevance of the behaviour of seabirds to the conservation of marine environments. Oikos, 77, 227-237.

Mulder, C., Jones, H., Kameda, K., Palmborg, C., Schmidt, S., ELLIS, J. et al. (2011) Impacts of seabirds on plant and soil properties. In Seabird Islands: Ecology, Invasion, and Restoration (eds C.P. H. Mulder, W.B. Anderson, D.R. Towns \& P.J. Bellingham), pp. 135176. Oxford University Press, New York, USA.

New Zealand Birds Online (2015) The digital encyclopaedia of New Zealand birds. Http://nzbirdsonline.org.nz/ [accessed 1 July 2015].

Nur, N. \& Sydeman, W.J. (1999) Demographic processes and population dynamic models of seabirds. Current Ornithology, 15, 149-188.

OKSANEN, L. (2001) Logic of experiments in ecology: is pseudoreplication a pseudoissue? Oikos, 94, 27-38.

Paradis, E., Claude, J. \& Strimmer, K. (2004) APE: analyses of phylogenetics and evolution in R language. Bioinformatics, 20, 289-290.

Parejo, D., Danchin, E. \& Avilés, J.M. (2005) The heterospecific habitat copying hypothesis: can competitors indicate habitat quality? Behavioral Ecology, 16, 96-105.

Pebesma, E.J. (2004) Multivariable geostatistics in S: the gstat package. Computers \& Geosciences, 30, 683-691.

Petersen, A. (2009) Formation of a bird community on a new island, Surtsey, Iceland. Surtsey Research, 12, 133-148.

Phillips, S.J., Anderson, R.P. \& Schapire, R.E. (2006) Maximum entropy modeling of species geographic distributions. Ecological Modelling, 190, 231-259.

Preston, F.W. (1962) The canonical distribution of commonness and rarity: part I. Ecology, 43, 185-215.

R Development Core Team (2013) R: A Language and Environment for Statistical Computing. R Foundation for Statistical Computing, Vienna, Austria.

Rayner, M.J., Clout, M.N., Stamp, R.K., Imber, M.J., Brunton, D. H. \& Hauber, M.E. (2007) Predictive habitat modelling for the population census of a burrowing seabird: a study of the endangered Cook's petrel. Biological Conservation, 138, 235-247.

Rayner, M.J., Gaskin, C.P., Fitzgerald, N.B., Baird, K.A., Berg, M.M., BOy LE, D. et al. (2015) Using miniaturized radiotelemetry to discover the breeding grounds of the endangered New Zealand storm petrel Fregetta maoriana. Ibis, 157, 754-766.

Rolland, V., Nevoux, M., Barbraud, C. \& Weimerskirch, H. (2009) Respective impact of climate and fisheries on the growth of an albatross population. Ecological Applications, 19, 1336-1346.

SChreiber, E. \& Burger, J. (2001) Biology of Marine Birds. CRC Press, Boca Raton, USA. 
Simberloff, D.S. (1974) Equilibrium theory of island biogeography and ecology. Annual Reviews of Ecological Systems, 5, 161-182.

SKEGG, P.D.G. (1963) Birds of the Mercury Islands group. Notornis, 10 , 153-168.

SLADDEN, B. \& FALLA, R.A. (1958) Island survey form. In Fogarty, S.M. \& Douglas, M.E. (1973) The birds of the Aldermen Islands, Tane, 19, 31-39.

Southey, I. (1985) Birds of Middle Island, Observations. Unpublished report.

Spatz, D.R., Newton, K.M., Heinz, R., Tershy, B., Holmes, N.D., Butchart, S.H.M. \& Croll, D.A. (2014) The biogeography of globally threatened seabirds and island conservation opportunities. Conservation Biology, 28, 1282-1290.

TAYLOR, G.A. (1989) A Register of Northern Offshore Islands and a Management Strategy for Island Resources. Department of Conservation, Wellington, New Zealand.

Thoresen, A.C. (1967) Ecological observations on Stanley and Green Islands, Mercury group. Notornis, 14, 182-199.

Towns, D.R. (2009) Eradications as reverse invasions: lessons from Pacific rat (Rattus exulans) removals on New Zealand islands. Biological Invasions, 11, 1719-1733.

Towns, D.R., Atrinson, I.A. \& Daugherty, C.H. (2006) Have the harmful effects of introduced rats on islands been exaggerated? Biological Invasions, 8, 863-891.

Towns, D.R. \& Broome, K.G. (2003) From small Maria to massive Campbell: forty years of rat eradications from New Zealand islands. New Zealand Journal of Zoology, 30, 377-398.

Towns, D.R., West, C.J. \& Broome, K.G. (2013) Purposes, outcomes and challenges of eradicating invasive mammals from New Zealand islands: an historical perspective. Wildlife Research, 40, 94-107.
VARnham, K. (2010) Invasive Rats on Tropical Islands: Their History, Ecology, Impacts and Eradication. RSPB, Sandy, UK.

Veitch, C., Gaskin, C., Baird, K. \& Ismar, S. (2011) Changes in bird numbers on Raoul Island, Kermadec Islands, New Zealand, following the eradication of goats, rats and cats. In Island Invasives: Eradication and Management (eds C.R. Veitch, M.N. Clout \& D.R. Towns), pp. 372-376. IUCN, Gland, Switzerland.

Veitch, C.R., Smuts-Kennedy, J.C., Moran, L.R. \& Batchelor, C. (1973) Island survey form. Unpublished; Wildlife Branch files.

Wolf, S., Keitt, B., Aguirre-Muñoz, A., Tershy, B., Palacios, E. \& CROLL, D. (2006) Transboundary seabird conservation in an important North American marine ecoregion. Environmental Conservation, 33, 294-305.

\section{Biographical sketches}

STEPHANIE BORRELLE's research includes island restoration and recovery processes, and how demography and at-sea threats may be influencing seabird recovery following land-based conservation actions. Philipp Boersch-Supan is a quantitative ecologist focused on marine ecosystems. He is particularly interested in the ecology of oceanic predators and their prey. CHRIS GASKIN conducts surveys and research on seabirds in northern New Zealand. He coordinated the Important Bird Area programme for New Zealand's seabirds. DAVID Towns's research has been based on understanding the effects of invasive predators on island ecosystems, investigating methods for restoring modified island ecosystems, and the development of biological and social metrics for measuring progress of restoration projects. 